\title{
Parthenolide Induces Reactive Oxygen Species-Mediated Autophagic Cell Death in Human Osteosarcoma Cells
}

\author{
Chen Yang ${ }^{\mathrm{a}}$ Qing Ou Yang ${ }^{\mathrm{b}}$ Qing-Jie Kong ${ }^{\mathrm{a}}$ Wen Yuan ${ }^{\mathrm{a}}$ Yue-Ping Ou Yang \\ aDepartment of orthopedic Surgery, Changzheng Hospital, Second Military Medical University, \\ Shanghai, ${ }^{b}$ Department of hepatobiliary surgery, center of liver transplantation, General Hospital of \\ Guangzhou Military Region, Guangzhou, China
}

\section{Key Words}

Parthenolide • Osteosarcoma cells • Autophagy • Apoptosis

\begin{abstract}
Background and Aim: Osteosarcoma is a devastating tumor of bone, primarily affecting adolescents. Parthenolide, a naturally occurring small molecule that interferes with NF-KB signaling, has recently attracted considerable attention because of its pharmacological action involving anti-cancer effects. However, the mechanism of the cytotoxic effect exerted by parthenolide on tumor cells is not clearly defined today. Methods: In this study, the effects of parthenolide were evaluated and characterized in human osteosarcoma cancer cell. Cell viability was assessed by CCK-8. Apoptosis was assessed by Annexin V-FITC/PI Flow cytometry assay. Relative quantitative real-time PCR and western blot were used to determine the expressions of genes and proteins. Results: Our results suggest that parthenolide did not cause caspasedependent cell death in osteosarcoma cancer cells, as indicated by the absence of significant early apoptosis as well as caspase- 3 cleavage. Instead, parthenolide increased the autophagy and mitophagy, as characterized by increased PINK1 and Parkin translocation to mitochondria and enhanced autophagy proteins. The induction of autophagy by parthenolide was associated with the increase of reactive oxygen species (ROS). ROS antioxidants $\mathrm{N}$-acetylcysteine (NAC) attenuated parthenolide-induced autophagy activity. Conclusions: Our findings unveil a novel mechanism of drug action by parthenolide in osteosarcoma cancer cells and suggest a potential value of treating osteosarcoma cancer through a caspase-independent autophagic cell death by ROS activation.
\end{abstract}

\section{Introduction}

(C) 2016 The Author(s) Published by S. Karger AG, Basel

Osteosarcoma (OS) which usually occurred in children and adolescents is the most common primary malignant bone tumor [1-3]. Chemotherapy, such as cisplatin, doxorubicin and methotrexate is the preferred choice treatment for OS. In the past few decades, neoadjuvant chemotherapy has increased the long-term survival rate of osteosarcoma C. Yang, Q. O. Yang and Q.-J. Kong are co first author for this work. 


\section{Cellular Physiology Cell Physiol Biochem 2016;40:146-154 \begin{tabular}{l|l|l}
\hline and Biochemistry 10.1159/000452532 & $\begin{array}{l}\text { C) } 2016 \text { The Author(s). Published by S. Karger AG, Basel } \\
\text { www.karger.com/cpb }\end{array}$ \\
\hline
\end{tabular} \\ Yang et al.: Parthenolide and Osteosarcoma}

patients up to about 80\% [4-6]. However, patients that are less responsive to these drugs have a poor prognosis but also with severe side effects. Therefore, exploring the novel treatment strategy for OS is urgently needed.

Parthenolide, a sesquiterpene lactone found in Tanacetum parthenium has recently attracted considerable attention because of its complex pharmacological action involving anti-microbial, anti-inflammatory, and anti-cancer effects [7]. Parthenolide induces cytotoxicity in many cancer cell lines without effect on normal tissues [8-10]. As to the effect of parthenolide on the OS cell and the underlying mechanisms is not still fully elucidated.

During the past decade, autophagy is a universal process whereby cellular components and damaged organelles are sequestered within autophagosomes for lysosomal degradation $[11,12]$. Autophagy has proven to be an essential pathway for cellular homeostasis and now widely implicated in pathophysiological processes, including cancer [13]. A number of studies have demonstrated a critical role for autophagy in osteosarcoma development, therapy and drug resistance [14-16]. However, the underlying molecular mechanisms of autophagymediated chemotherapy resistance in osteosarcoma cells remain largely unknown.

In current study, we administrated osteosarcoma cell line with parthenolide and examined its biological effects in osteosarcoma cell line. Our results demonstrated that parthenolide robustly induce generation of reactive oxygen species, followed by a autophagydependent and caspase-independent form of death. These results provided new insight into the potential role of parthenolide in inducing autophagy but not apoptosis in human osteosarcoma cancer cells through ROS.

\section{Materials and Methods}

\section{Reagents and antibodies}

Parthenolide was supplied by Sigma-Aldrich. Stock solution of parthenolide was prepared in dimethyl sulfoxide (DMSO) and diluted to final concentration in the culture medium. All reagents were purchased from Sigma-Aldrich, except for z- VAD-fmk, which were supplied from Promega.

\section{Cell culture}

Saos -2 and MG-63 cells were purchased from ATCC, All these two cells were maintained under standard culture conditions $\left(37^{\circ} \mathrm{C}, 5 \% \mathrm{CO}_{2}\right)$ in culture medium recommended by ATCC.

\section{CCK8 cell viability assays}

Cells were seeded into a 96 -well plate at $8 \times 10^{3}$ cells per well with $100 \mu$ l cultured medium and cultured at $37{ }^{\circ} \mathrm{C}, 5 \% \mathrm{CO}_{2}$. The cell viability was quantified as previous by addition $10 \mu \mathrm{l}$ of cell counting kit (CCK8, Dojindo) [17]. After 1.5 hours incubation, the plates were monitored by Power Wave XS microplate reader (BIO-TEK) at an absorbance $450 \mathrm{~nm}$.

Analysis of cleaved-caspase-3-positive cells by flow cytometry

Cells containing cleaved caspase-3 were examined using a cleaved caspase-3 (Asp175) antibody (Alexa Fluor 488 conjugate). Briefly, the cells were fixed in $2 \%$ formaldehyde for $10 \mathrm{~min}$ and then permeabilized in $90 \%$ methanol for $30 \mathrm{~min}$ on ice. After permeabilization, the cells were incubated in PBS containing the fluorochrome-conjugated antibody for $30 \mathrm{~min}$ at room temperature and then analyzed on the FACS can flow cytometer.

Flow cytometry cell apoptosis assays

The indicated cells ( $20 \times 10^{4} /$ well) were seeded in the 6-well plates and treated with parthenolide and Cis. Then these cells were collected at $24 \mathrm{~h}$. Cells were washed twice with $1 \mathrm{X}$ cold PBS, and then stained with Annexin V-FITC/PI (BD), all the procedure was according to the manufacture's protocol as previous study [18]. 


\section{Cellular Physiology Cell Physiol Biochem 2016;40:146-154 \begin{tabular}{l|l|l} 
and Biochemistry Published online: November 18, 2016 & $\begin{array}{l}\text { C } 2016 \text { The Author(s). Published by S. Karger AG, Basel } \\
\text { www.karger.com/cpb }\end{array}$
\end{tabular} \\ Yang et al.: Parthenolide and Osteosarcoma}

Measurement of fluorescent LC3 puncta

Imaging studies for GFP-LC3 in cells were performed as previously described. Briefly, Saos-2 cells cultured on coverslips were transduced with Ad-GFP-LC3. Two hours later, the culture media containing virus were replaced with fresh media. After the treatment, the cells were washed with PBS, fixed with $4 \%$ paraformaldehyde, and viewed under Leica TCS SP2 confocal laser scanning microscope. The number of GFP dots was determined by manual counting of fluorescent puncta.

Small interfering RNA (siRNA) transfection and treatments

The siRNAs were obtained from GenePharma, Inc, including siControl nontargeting pool and against human ATG5, PINK1 and Parkin. The following transfection process with Invitrogen RNAiMAX was according to the manufacturer's instructions. After $36 \mathrm{~h}$ treatment, cells were harvested for Western blot or cell death quantification.

RNA isolation and quantitative real-time PCR

Total RNA was purified from CCA and adjacent tissues or cells using TRIzol (Invitrogen) following the manufacturer's protocol. RNA (1 $\mu \mathrm{g})$ was reverse transcribed using SuperScript Reverse Transcriptase III (Invitrogen). Quantitative real time PCR was performed using SYBR green Supermix (ABI) in ABI 7500 PCR system. Housekeeping gene GAPDH was used as an internal standard.

Western blots

Cells were lysed in WB/IP lysis buffer (P0013, Beyotime), all the procedures were following the manufacturer's protocol. Subsequently the cell lysates were boiled in 5X SDS-PAGE loading buffer for $10 \mathrm{~min}$ and then resolved by $8 \%$ SDS-PAGE and transferred to nitrocellulose membrane. The following antibodies were used in this study: LC3 (Sigma), Beclin 1 (CST), PINK1 (CST), Parkin (CST), GAPDH (Proteintech). Bound antibodies were visualized with the ECL kit (Thermo Scientific).

\section{Statistical analysis}

Statistical analysis was performed using Student's $t$ test for comparison of two groups or one-way analysis of variance for comparison of more than two groups followed by Tukey's multiple comparison test. For multiple testing, a Bonferroni post hoc test of $p$ values was done. Statistical calculations were performed using a software from GraphPad Prism (GraphPad, San Diego, CA, USA). Data were expressed as means \pm SEM of at least three independent experiments. A $p$ value $<0.05$ was considered statistically significant.

\section{Results}

Parthenolide induces caspase-independent cell death in human osteosarcoma cancer cells The dose dependence of the effect exerted by parthenolide on the viability of Saos -2 and MG-63 cells were performed. To this end cells we treated for various doses $(0-25 \mu \mathrm{M})$ of parthenolide or an apoptotic agent, $20 \mu \mathrm{M}$ cisplatin (Cis), followed by the assessment of cell viability with CCK8 assay. Like cisplatin, parthenolide elicited a significant decrease in cell viability in Saos -2 and MG-63 cells (Fig. 1A). Trypan blue exclusion assay showed that parthenolide increased cell death in dose-dependent manner (Fig. 1B).

To examine the early events of apoptosis, Saos -2 and MG-63 cells were treated with cisplatin and parthenolide, and then analyzed by Annexin V/PI staining. The results shown that the percentage of Annexin V-FITC-positive cells in parthenolide-treated Saos-2 cells was much low compared with the Cis-treated cells (Fig. 2A), indicating that parthenolide induced little or no apoptosis in Saos-2 cells. This was confirmed by analyzing the level of cleaved caspase-3 (Fig. 2B). To further determine whether Saos-2 and MG-63 cells death induced by parthenolide were caspase-independent, we examined the effect of the pancaspase inhibitor zVAD-fmk on parthenolide-induced cell death. Nevertheless, cell death induced by Cis was significantly blocked in Saos -2 and MG- 63 cells, cell death induced by parthenolide was hardly affected by zVAD-fmk (Fig. 2C-2D). So in conclusion these data indicate that, in 


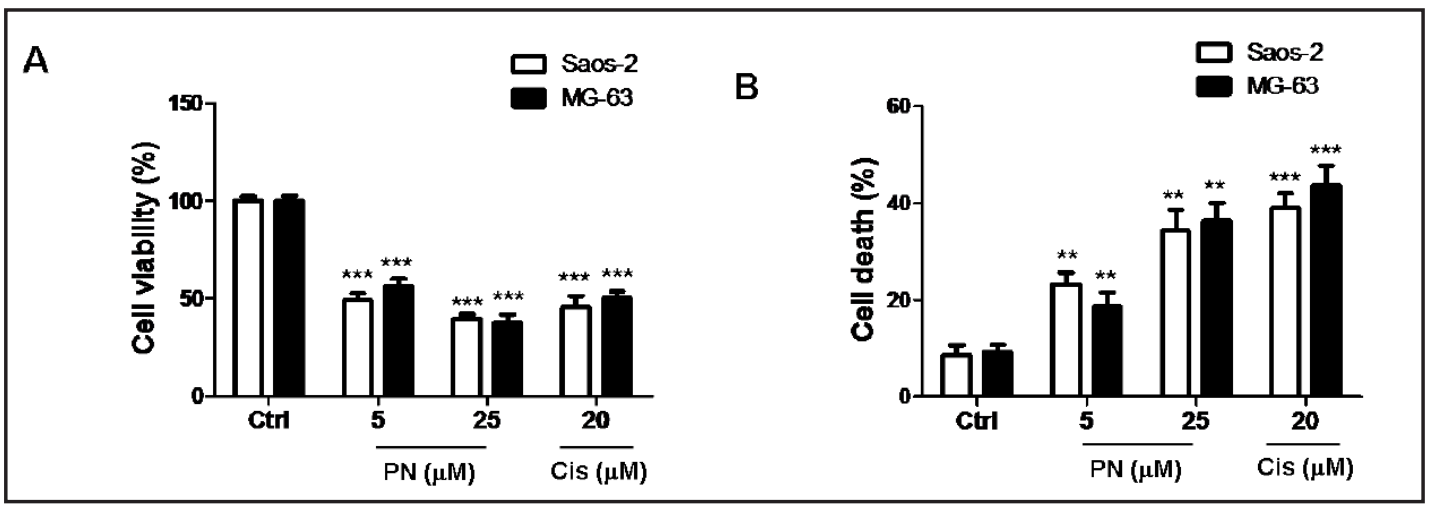

Fig. 1. Parthenolide induces cell death in human osteosarcoma cancer cells. Saos -2 and MG-63 cells were treated with parthenolide $(5,25 \mu \mathrm{M}$ ) and $20 \mu \mathrm{M}$ cisplatin (Cis) for $48 \mathrm{~h}$ and then assessed by CCK8 assay (A) and the trypan blue exclusion assay (B). ${ }^{* *} \mathrm{P}<0.01,{ }^{* * *} \mathrm{P}<0.001$ vs corresponding control group.

Fig. 2. Parthenolide induces caspase-independent cell death in human osteosarcoma cancer cells. (A) Saos-2 and MG-63 cells were treated with parthenolide $(5,25 \mu \mathrm{M})$ and 20 $\mu \mathrm{M}$ cisplatin (Cis) for $48 \mathrm{~h}$ and then stained with annexin V/PI, and analyzed by flow cytometry. (B) Saos -2 cells were treated with parthenolide or Cis. Apoptotic cells were labeled with the Alexa Fluor 488-conjugated antibody against cleaved caspase-3 (Asp175) and quantified by flow cytometry. (C) Effects of the pancaspase inhibitor zVAD-fmk on cell death induced by parthenolide. ${ }^{*} \mathrm{P}<0.05$, $* * \mathrm{P}<0.01, \quad * * * \mathrm{P}<0.001$ vs corresponding control group.

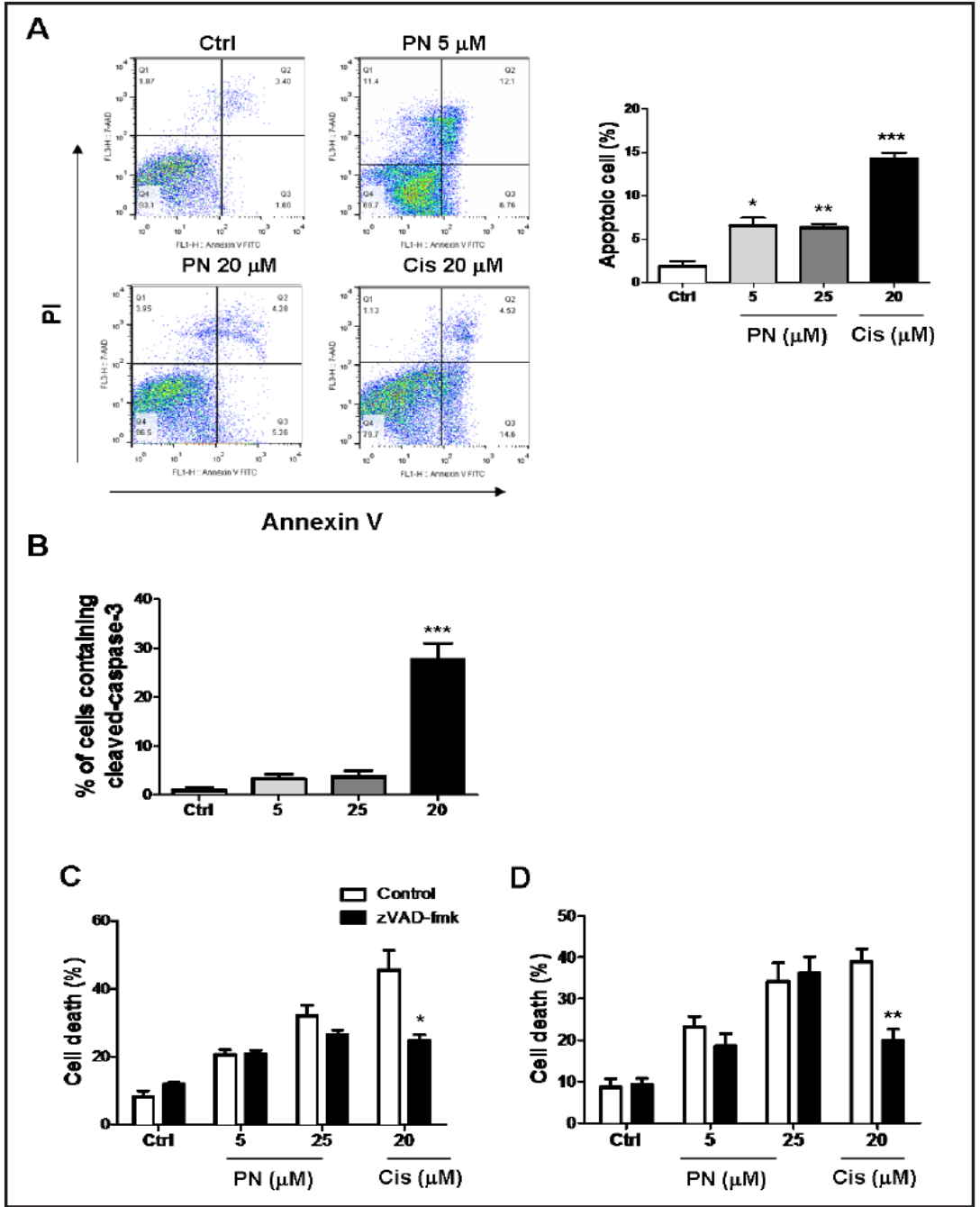

contrast to Cis, which clearly acts via a caspase-dependent apoptotic pathway, parthenolide induces osteosarcoma cancer cells death through a caspase-independent pathway. 


\section{Cellular Physiology Cell Physiol Biochem 2016;40:146-154 and Biochemistry Published online: November 18, 2016 \begin{tabular}{l|l} 
DOI: 10.1159/000452532 2016 The Author(s). Published by S. Karger AG, Basel \\
www.karger.com/cpb
\end{tabular} Yang et al.: Parthenolide and Osteosarcoma}

Fig. 3. Parthenolide induces autophagy in human osteosarcoma cancer cells. (A) Saos-2 cells were transfected with adenovirus encoding GFP-LC3. Representative (upper panel) and analysis (lower panel) of immunofluorescence images of Saos -2 cells expressing green fluorescent protein-light chain-3 (LC3) and LC3 puncta (indicator of autophagosomes) in Saos-2 cells after $36 \mathrm{~h}$ infection of Ad-GFPLC3 (40 multiplicities of infection). (B) Representative immunoblots (upper panel) and quantitative analysis (lower panel) of light chain-3 (LC3)-II expression in myocardial Saos -2 cells lysis with and without parthenolide treatment. ${ }^{*} \mathrm{P}<0.05$, ${ }^{* *} \mathrm{P}<0.01$, $* * * \mathrm{P}<0.001$ vs control group.

Parthenolide induces mitophagy in human osteosarcoma cancer cells

Above results demonstrated that apoptosis did not involved in parthenolide induces osteosarcoma cancer cells death, then we examined whether and how programmed cell death type II, autophagy plays a role in parthenolide-induced cell death. Parthenolide treatment significantly increased the conversion of LC3-I to LC3II, an established indicator of autophagy (Fig. 3B). To further confirm the induction of autophagosomes by parthenolide, we transfected cells with adenovirus encoding GFP-LC3, in which the punctate staining pattern of GFP-LC3 was observed. The parthenolide treatment significantly
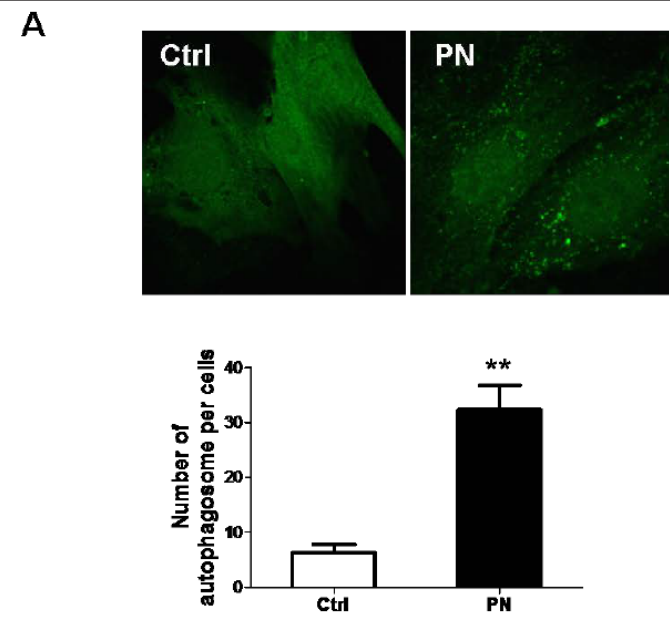

B
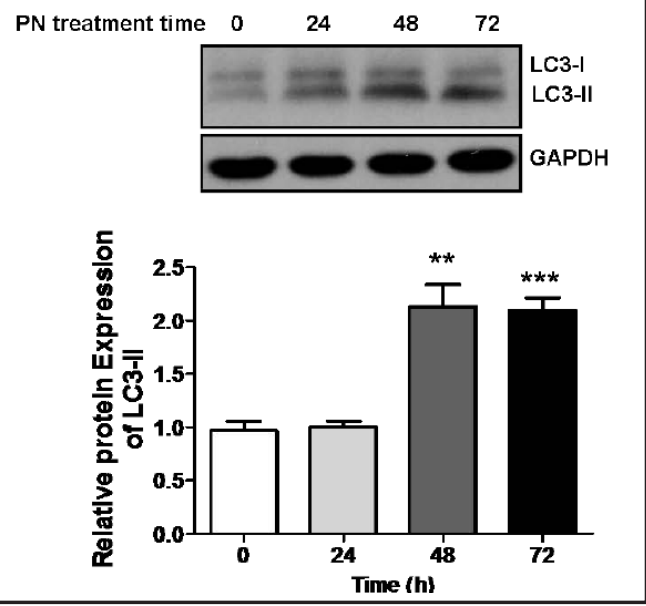
increased the dots of GFP-LC3 (Fig. 3A). Those results suggest that parthenolide induces autophagy in human osteosarcoma cancer cells.

Of note, mitophagy as a selective form of autophagy induces autophagic clearance of dysfunctional mitochondria through specialized molecules to sense damaged mitochondria [19]. We next sought to determine the dynamic changes of PINK1/Parkin mediated mitophagy. As Figure 4B illustrated, the protein expression of PINK1 and Parkin in cytosol lysates increased with parthenolide treatment, which is counter to the expression in mitochondrial extraction. These results suggested that parthenolide stimulated PINK1/Parkin mediated mitophagy due to insufficient mitochondrial translocation of PINK1 and Parkin. In addition, co-localization of LC3 (GFP-LC3), a marker of autophagosomes and mitochondria (MitoTracker) was evaluated for detection of mitophagy. Quantification of co-localization showed that more mitochondria and autophagosomes were co-localized in parthenolide-treated MG-63 cells (Fig. 4C), suggesting that mitophagy was induced under parthenolide treatment.

\section{Parthenolide-induced cell death attributable to mitophagy}

Real time PCR analysis and western blot analysis shown that autophagy related gene including Beclin 1 and Atg5 were significantly increased with parthenolide treatment in a time-dependent manner (Fig. 4A). To verify autophagy and mitophagy is responsible for parthenolide-induced cell death, we silenced Atg5, PINK1 and Parkin separately by siRNA. and then cell death was evaluated. The percentage of cell death was also reduced in Atg5, PINK1 and Parkin knockdown Saos-2 and MG-63 cells, suggested that stimulated autophagy and mitophagy is involved in parthenolide-induced cell death (Fig. 4D). 
Fig. 4. Mitophagy is responsible for parthenolide-induced cell death in human osteosarcoma cancer cells. (A) ATG5 or Beclin 1 mRNA expression was examined by real time-PCR, GAPDH was used as an internal standard. (B) Mitophagy related protein expression was examined by western blot. (C) Saos-2 and MG-63 cell death were examined by trypan blue. ${ }^{*} \mathrm{P}<0.05,{ }^{* *} \mathrm{P}<0.01$ vs parthenolide group.

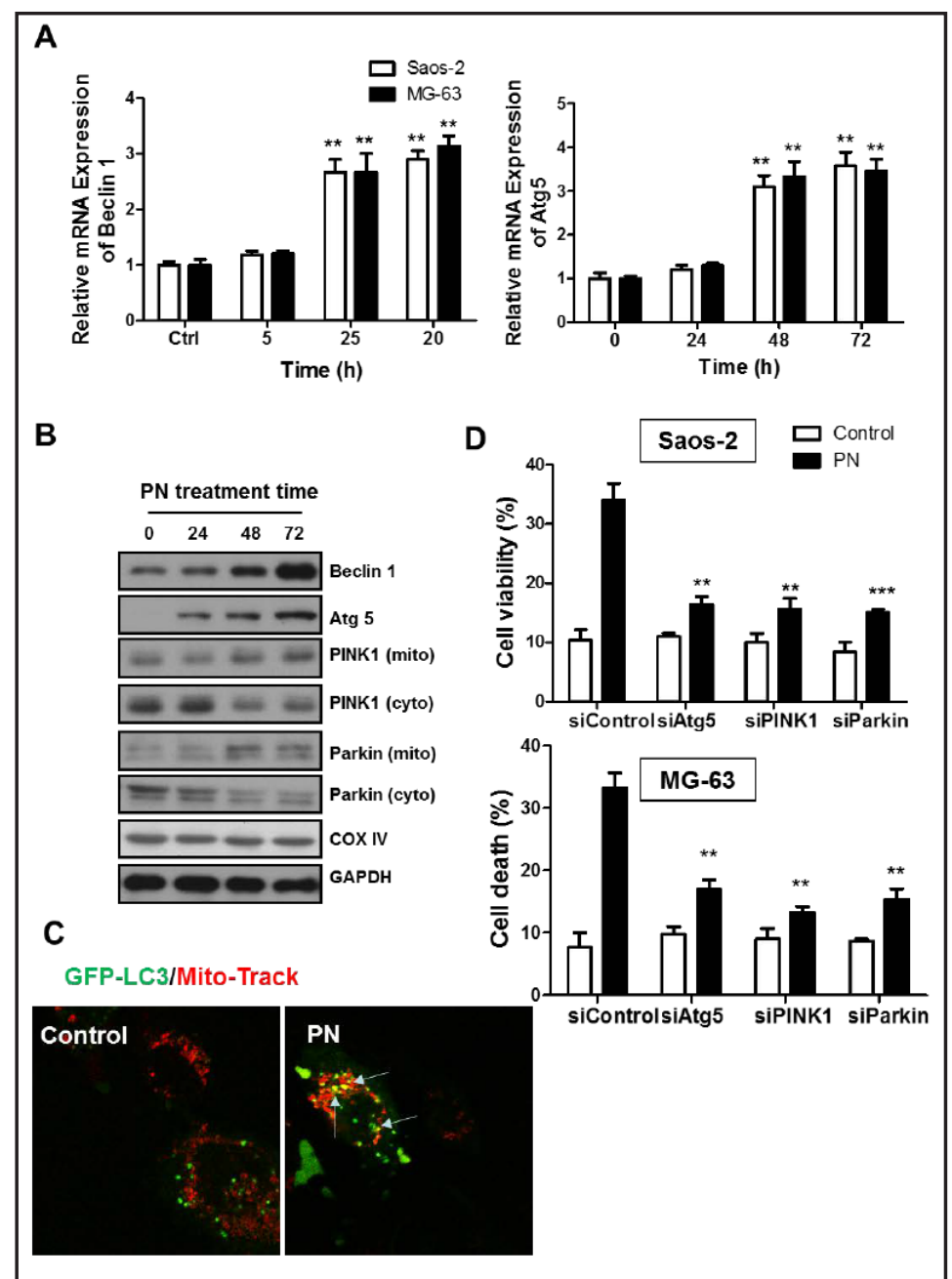

Parthenolide induces autophagy-mediated cell death via ROS generation

Many lines of evidence indicate that parthenolide induces oxidative stress by increasing production of ROS. To elucidate the mechanism of how parthenolide induces autophagy in osteosarcoma cancer cells. Then we examined the ROS level with DCF fluorescence by flow cytometry. Results showed that parthenolide could increase ROS generation in a time-dependent manner (Fig. 5A). This increase was significantly attenuated when the osteosarcoma cancer cells were pretreated with the antioxidants NAC (data not shown). To determine the role of ROS in the process of parthenolide-induced autophagy. Further results showed that the NAC could attenuate parthenolide-afforded accumulation of LC3-II (Fig. 5B). To further characterize the effect of antioxidants on parthenolide-induced autophagic cells death, we examined the effect of NAC on the parthenolide-induced cell death. Our data suggest that NAC could significantly block parthenolide-induced cell death (Fig. 5C). Taken together, these results suggest that the generation of ROS induced by parthenolide plays an important role in the increase in autophagy followed by cell death.

\section{Discussion}

Parthenolide, the anti-inflammatory phytochemical, has been shown able to suppress tumor growth in many organs $[4,8,9,20]$. In addition, parthenolide seems to synergically enhance chemotherapeutic efficiency when combination with Taxol or cisplatin to treat lung 
Fig. 5. ROS generation is involved in parthenolide-induced cell death in human osteosarcoma cancer cells. (A) ROS levels were measured with DCF fluorescence by flow cytometry. Saos -2 cells were treated with parthenolide for 24,48 , or $72 \mathrm{~h}$, stained with DCFDA for $30 \mathrm{~min}$, and then analyzed by flow cytometry. ${ }^{*} \mathrm{P}<0.05,{ }^{* *} \mathrm{P}<0.01$ vs control group. (B) LC3-II protein expression was examined by western blot. (C) effect of NAC on the Saos-2 and MG-63 cell death were examined by trypan blue with and without parthenolide treatment. $\quad{ }^{*} \mathrm{P}<0.05 \quad v s$ parthenolide group.

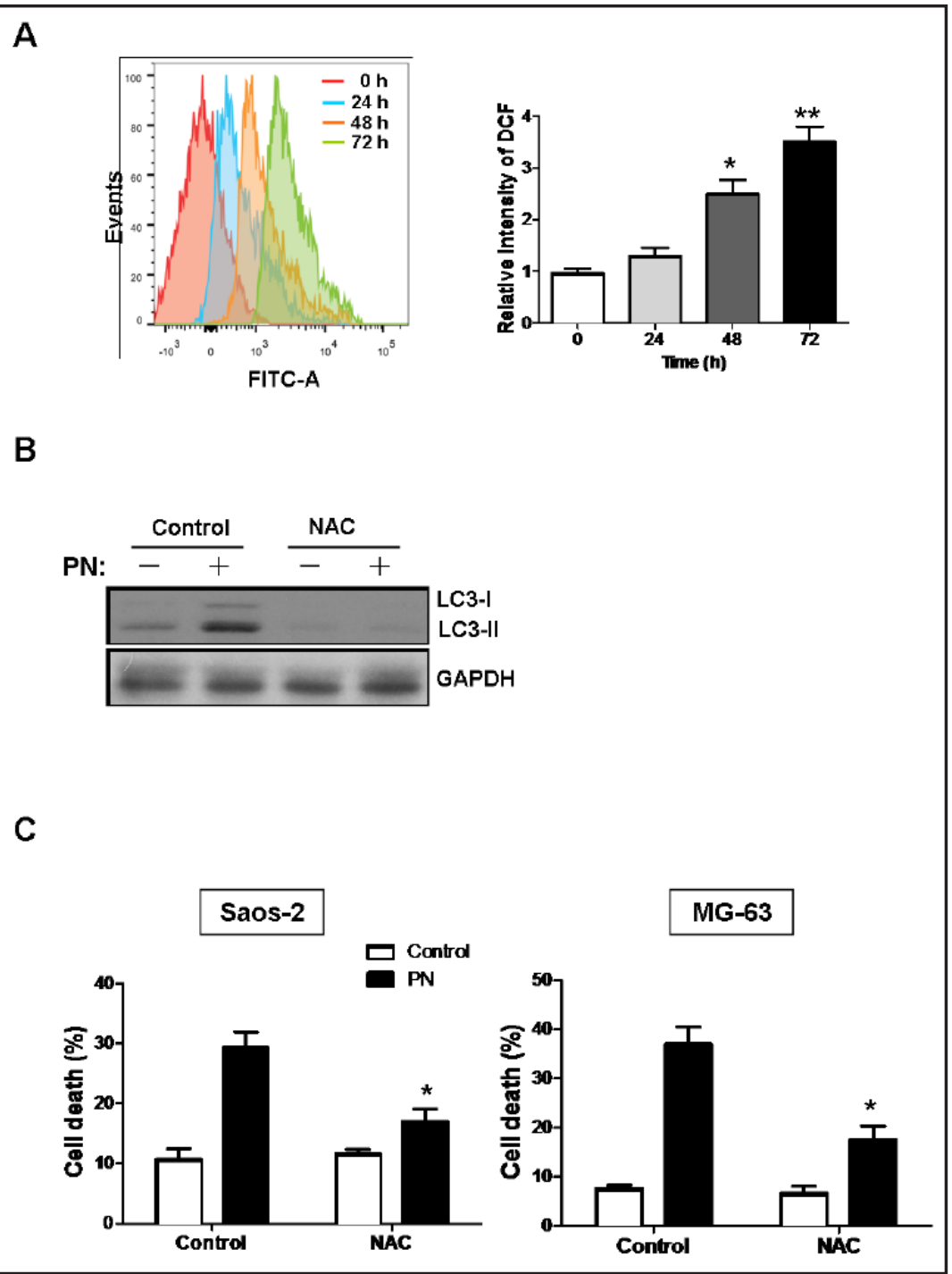

and gastric cancer cells $[9,21]$. However, the signaling pathways underlying parthenolideinduced cell death have not been fully elucidated. In current study, we explored the biological effects of parthenolide in human osteosarcoma cancer cells and for the first time report that parthenolide induced a autophagy-dependent and caspase-independent form of death, which is through ROS generation. Our results shed the lights that parthenolide obtains the potential to be an agent for osteosarcoma cancer treatment.

Autophagy, an intracellular self-protective mechanism, not only prevents the toxic accumulation of damaged components but also recycles the degraded components to sustain metabolic homeostasis. Autophagy is involved in the promotion or inhibition of cancer cell death, which is dependent on the cellular context as well as the strength and duration of the stress stimuli $[22,23]$. Blocking cancer cell autophagy is emerging as a novel approach to enhance the efficiency of chemotherapy in cancer treatment. Our data presented here demonstrated that induction of autophagy and mitophagy by parthenolide significantly causes cell death in OS cancer cells. Besides, we did not find any increase in caspase- 3 cleavage during parthenolide treatment in Saos-2 and MG-63 cells.

Redox homeostasis is essential for maintenance of normal physiologic conditions but is aberrantly modulated in cancers, including OS [24]. ROS, as products of cell metabolism, play a beneficial or deleterious role in tumorigenesis and tumor suppression [25]. Recently, caspase-independent autophagic cell death has been reported to associate with alterations 


\section{Cellular Physiology Cell Physiol Biochem 2016;40:146-154 \begin{tabular}{l|l|l}
\hline and aiochemistry 10.1159/000452532 & $\begin{array}{l}\text { C) 2016 The Author(s). Published by S. Karger AG, Basel } \\
\text { www.karger.com/cpb }\end{array}$ \\
\hline
\end{tabular} \\ Yang et al.: Parthenolide and Osteosarcoma}

in ROS [26, 27]. Our results shown that ROS is significantly generated after parthenolide treatment and ROS scavenger NAC abolished parthenolide-induced autophagy stimulation followed by improved cell viability. Our study demonstrated that ROS generation was involved in parthenolide-induced caspase-independent autophagic cell death in OS cancer cells.

In conclusion, the present study has demonstrated that parthenolide as a potent agent in inducing autophagy in human OS cancer cells through a ROS-dependent pathway. Our study sheds new light on the mechanism by which parthenolide induced cell death of OS cell lines through caspase-independent mechanism.

\section{Acknowledgements}

This study was supported by National Natural Science Foundation of China (81271236).

\section{Disclosure Statement}

No potential conflicts of interest were disclosed.

\section{References}

1 Ottaviani G, Jaffe N: The epidemiology of osteosarcoma. Cancer Treat Res 2009;152:3-13.

2 Marko TA, Diessner BJ, Spector LG: Prevalence of Metastasis at Diagnosis of Osteosarcoma: An International Comparison. Pediatr Blood Cancer 2016;63:1006-1011.

3 Li Y, Wagner ER, Yan Z, Wang Z, Luther G, Jiang W, Ye J, Wei Q, Wang J, Zhao L, Lu S, Wang X, Mohammed MK, Tang S, Liu H, Fan J, Zhang F, Zou Y, Song D, Liao J, Haydon RC, Luu HH, He TC: The Calcium-Binding Protein S100A6 Accelerates Human Osteosarcoma Growth by Promoting Cell Proliferation and Inhibiting Osteogenic Differentiation. Cell Physiol Biochem 2015;37:2375-2392.

4 Yang ZJ, Chee CE, Huang S, Sinicrope FA: The role of autophagy in cancer: therapeutic implications. Mol Cancer Ther 2011;10:1533-1541.

5 Goorin AM, Schwartzentruber DJ, Devidas M, Gebhard MC, Ayala AG, Harris MB, Helman LJ, Grier HE, Link MP, Pediatric Oncology G: Presurgical chemotherapy compared with immediate surgery and adjuvant chemotherapy for nonmetastatic osteosarcoma: Pediatric Oncology Group Study POG-8651. J Clin Oncol 2003;21:1574-1580.

6 Provisor AJ, Ettinger LJ, Nachman JB, Krailo MD, Makley JT, Yunis EJ, Huvos AG, Betcher DL, Baum ES, Kisker CT, Miser JS: Treatment of nonmetastatic osteosarcoma of the extremity with preoperative and postoperative chemotherapy: a report from the Children's Cancer Group. J Clin Oncol 1997;15:76-84.

7 Hwang DR, Wu YS, Chang CW, Lien TW, Chen WC, Tan UK, Hsu JT, Hsieh HP: Synthesis and anti-viral activity of a series of sesquiterpene lactones and analogues in the subgenomic HCV replicon system. Bioorg Med Chem 2006;14:83-91.

8 Pajak B, Gajkowska B, Orzechowski A: Molecular basis of parthenolide-dependent proapoptotic activity in cancer cells. Folia Histochem Cytobiol 2008;46:129-135.

9 Gill KK, Kaddoumi A, Nazzal S: Mixed micelles of PEG(2000)-DSPE and vitamin-E TPGS for concurrent delivery of paclitaxel and parthenolide: enhanced chemosenstization and antitumor efficacy against nonsmall cell lung cancer (NSCLC) cell lines. Eur J Pharm Sci 2012;46:64-71.

10 Sun Y, St Clair DK, Fang F, Warren GW, Rangnekar VM, Crooks PA, St Clair WH: The radiosensitization effect of parthenolide in prostate cancer cells is mediated by nuclear factor-kappaB inhibition and enhanced by the presence of PTEN. Mol Cancer Ther 2007;6:2477-2486.

11 Levine B, Kroemer G: Autophagy in the pathogenesis of disease. Cell 2008;132:27-42. 


\section{Cellular Physiology Cell Physiol Biochem 2016;40:146-154 \begin{tabular}{l|l|l} 
DOI: 10.1159/000452532 & $\begin{array}{l}\text { O 2016 The Author(s). Published by S. Karger AG, Basel } \\
\text { www.karger.com/cpb }\end{array}$
\end{tabular} \\ Yang et al.: Parthenolide and Osteosarcoma}

12 Mizushima N, Levine B, Cuervo AM, Klionsky DJ: Autophagy fights disease through cellular self-digestion. Nature 2008;451:1069-1075.

13 Choi AM, Ryter SW, Levine B: Autophagy in human health and disease. N Engl J Med 2013;368:651-662.

14 Livesey KM, Tang D, Zeh HJ, Lotze MT: Autophagy inhibition in combination cancer treatment. Curr Opin Investig Drugs 2009;10:1269-1279.

15 White E, DiPaola RS: The double-edged sword of autophagy modulation in cancer. Clin Cancer Res 2009;15:5308-5316.

16 Mathew R, Karantza-Wadsworth V, White E: Role of autophagy in cancer. Nat Rev Cancer 2007;7:961-967.

17 Hu KH, Li WX, Sun MY, Zhang SB, Fan CX, Wu Q Zhu W, Xu X: Cadmium Induced Apoptosis in MG63 Cells by Increasing ROS, Activation of p38 MAPK and Inhibition of ERK 1/2 Pathways. Cell Physiol Biochem 2015;36:642-654.

$18 \mathrm{Hu}$ W, Xiao Z: Formononetin induces apoptosis of human osteosarcoma cell line U2OS by regulating the expression of Bcl-2, Bax and MiR-375 in vitro and in vivo. Cell Physiol Biochem 2015;37:933-939.

19 Jin SM, Youle RJ: PINK1- and Parkin-mediated mitophagy at a glance. J Cell Sci 2012;125:795-799.

20 Sun Y, St Clair DK, Xu Y, Crooks PA, St Clair WH: A NADPH oxidase-dependent redox signaling pathway mediates the selective radiosensitization effect of parthenolide in prostate cancer cells. Cancer Res 2010;70:2880-2890.

21 Sohma I, Fujiwara Y, Sugita Y, Yoshioka A, Shirakawa M, Moon JH, Takiguchi S, Miyata H, Yamasaki M, Mori M, Doki Y: Parthenolide, an NF-kappaB inhibitor, suppresses tumor growth and enhances response to chemotherapy in gastric cancer. Cancer Genomics Proteomics 2011;8:39-47.

22 Amaravadi RK, Yu D, Lum JJ, Bui T, Christophorou MA, Evan GI, Thomas-Tikhonenko A, Thompson CB: Autophagy inhibition enhances therapy-induced apoptosis in a Myc-induced model of lymphoma. J Clin Invest 2007;117:326-336.

23 Kanzawa T, Zhang L, Xiao L, Germano IM, Kondo Y, Kondo S: Arsenic trioxide induces autophagic cell death in malignant glioma cells by upregulation of mitochondrial cell death protein BNIP3. Oncogene 2005;24:980-991.

24 D'Autreaux B, Toledano MB: ROS as signalling molecules: mechanisms that generate specificity in ROS homeostasis. Nat Rev Mol Cell Biol 2007;8:813-824.

25 Xia C, Meng Q, Liu LZ, Rojanasakul Y, Wang XR, Jiang BH: Reactive oxygen species regulate angiogenesis and tumor growth through vascular endothelial growth factor. Cancer Res 2007;67:10823-10830.

26 Gao M, Yeh PY, Lu YS, Hsu CH, Chen KF, Lee WC, Feng WC, Chen CS, Kuo ML, Cheng AL: OSU-03012, a novel celecoxib derivative, induces reactive oxygen species-related autophagy in hepatocellular carcinoma. Cancer Res 2008;68:9348-9357.

27 Borsello T, Croquelois K, Hornung JP, Clarke PG: N-methyl-d-aspartate-triggered neuronal death in organotypic hippocampal cultures is endocytic, autophagic and mediated by the c-Jun $\mathrm{N}$-terminal kinase pathway. Eur J Neurosci 2003;18:473-485. 